\title{
Aluminium surface treatment with ceramic phases using diode laser
}

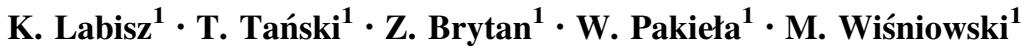

Received: 9 October 2015/ Accepted: 3 June 2016/Published online: 14 June 2016

(c) The Author(s) 2016. This article is published with open access at Springerlink.com

\begin{abstract}
Ceramic particles powder feeding into surface layer of engineering metal alloy is a well-known and widely used technique. New approach into the topic is to obtain finely distributed nano-sized particles involved in the aluminium matrix using the traditional laser technology. In this paper are presented results of microstructure investigation of cast aluminium-silicon-copper alloys surface layer after heat treatment and alloying with ceramic carbides of $\mathrm{WC}$ and $\mathrm{ZrO}_{2}$ using high-power diode laser. The surface layer was specially prepared for the reason of reducing the reflectivity, which is the main problem in the up-to-date metal matrix composites production. With scanning electron microscopy, it was possible to determine the deformation process and distribution of $\mathrm{WC}$ and $\mathrm{ZrO}_{2}$ ceramic powder phase. Structure of the surface after laser treatment changes, revealing three zones-remelting zone, heat-affected zone and transition zone placed over the $\mathrm{Al}$ substrate. The structural changes of ceramic powder, its distribution and morphology as well as microstructure of the matrix material influence on functional properties, especially wear resistance and hardness of the achieved layer, were investigated.
\end{abstract}

K. Labisz

krzysztof.labisz@polsl.pl

1 Division of Materials Processing Technology, Management and Computer Techniques in Materials Science, Institute of Engineering Materials and Biomaterials, Silesian University of Technology, Konarskiego Str 18A, 44-100 Gliwice, Poland

\section{Introduction}

Contemporary world imposes many restrictions over every engineering aspect (functionality, fabrication method, materials and all of its treatments) to fit into ecological-economical trend that was formed to slow down devastating human greed for consumption of Earth's resources by responsible and balanced development. One of its key aspects is reducing weight of every possible mobile element. Principle of conservation of energy teaches us that the heavier the detail is, more energy is necessary to move it. To produce energy, resources are needful. Resources are limited, so the calculus is clear-we need lightest parts in mobile constructions as possible. Light alloys like aluminium, titanium, magnesium are being taken into consideration while choosing material for application where weight is a key factor $[1,2]$.

Aluminium alloys are known for their low density which is close to $2.7 \mathrm{~g} \mathrm{~cm}^{-3}$ and fabrication facility [3-5]. For this reason, within a wide range of applications, especially in the transport industry, they are being exploited commonly [6-9]. However, aluminium alloys exhibit weak tribological characteristics which lead to reduction of their use in many other applications [10-13]. Surface processing of these alloys is modern way of bypassing many of its limitations. Modern surface processing technology, laser treatment, is widely used for pad welding and alloying of many engineering materials to obtain surface layers that are characterized by different properties than base material [1, 2, 14-17]. Laser surface alloying LSA of aluminium is useful surface treatment technique because it offers advantage of localized processing and with proper process parameters it is capable of homogenous structure formation with strong bonding to 
substrate surface. Moreover, there are various reports confirming that the laser surface alloying of aluminium does improve considerably the tribological characteristics at the surface $[1,2,18-24]$.

Goal of the research group was to check the influence of laser alloying of $\mathrm{ZrO}_{2}$ and $\mathrm{WC}$ powders into $\mathrm{AlSi}_{7} \mathrm{Cu}_{2}$ and $\mathrm{AlSi}_{9} \mathrm{Cu}_{2}$ aluminium cast alloys after heat treatment on material's morphology, chemical composition and hardness.

\section{Experimental procedure}

\subsection{Material for investigation}

Base materials used for investigation were $\mathrm{AlSi}_{7} \mathrm{Cu}_{2}$ and $\mathrm{AlSi}_{9} \mathrm{Cu}_{2}$ aluminium cast alloys whose chemical compositions are presented in Table 1. Samples have been heat treated. Process took place in electric resistance furnace U117, with a heating rate of $80{ }^{\circ} \mathrm{C} / \mathrm{s}$ for the ageing process and $300{ }^{\circ} \mathrm{C} / \mathrm{s}$ for the solution heat treatment process with two holds at $300{ }^{\circ} \mathrm{C}$ and $450{ }^{\circ} \mathrm{C}$ performed for $15 \mathrm{~min}$. Samples cooling was performed in air for the ageing process and in water for the solution heat treatment process. The solution heat treatment temperature was $505^{\circ} \mathrm{C}$ for $10 \mathrm{~h}$, and then ageing was performed at $175^{\circ} \mathrm{C}$ for $12 \mathrm{~h}$. Samples have been cut into $20 \mathrm{~mm} \times 30 \mathrm{~mm} \times 50 \mathrm{~mm}$ rectangular prisms. Surface layers were specially prepared for the reason of reducing reflectivity that is the main problem in the up-to-date MMC (Metal Matrix Composites) production. In order to achieve optimum reflectivity value, samples were etched in 60-s time. Additional materials used for alloying were zirconium dioxide $\mathrm{ZrO}_{2}$ and tungsten carbide WC powders whose properties are presented in Table 2, and their morphology is shown in Figs. 1, 2.

Table 1 Chemical composition of the investigated aluminium alloys Chemical composition of the investigated alloys (in mass\%)

\begin{tabular}{|c|c|c|}
\hline Alloys & $\mathrm{AlSi}_{7} \mathrm{Cu}_{2}$ & $\mathrm{AlSi}_{9} \mathrm{Cu}_{2}$ \\
\hline Elements & \multicolumn{2}{|c|}{ Chemical composition (mass\%) } \\
\hline $\mathrm{Si}$ & 7.16 & 7.44 \\
\hline $\mathrm{Fe}$ & 0.13 & 0.16 \\
\hline $\mathrm{Cu}$ & 0.99 & 3.59 \\
\hline $\mathrm{Mn}$ & 0.11 & 0.25 \\
\hline $\mathrm{Mg}$ & 0.26 & 0.28 \\
\hline $\mathrm{Zn}$ & 0.04 & 0.05 \\
\hline $\mathrm{Ti}$ & 0.08 & 0.12 \\
\hline $\mathrm{Al}$ & Rest & Rest \\
\hline
\end{tabular}

Table 2 Physical properties of the ceramic tungsten carbide powder WC

\begin{tabular}{lll}
\hline Properties & WC & $\mathrm{ZrO}_{2}$ \\
\hline Density $\left(\mathrm{g} / \mathrm{cm}^{3}\right)$ & 15.69 & 5.56 \\
Hardness $\mathrm{HV}\left(\mathrm{Kg} / \mathrm{mm}^{2}\right)$ & 2400 & 1300 \\
Melting temperature $\left({ }^{\circ} \mathrm{C}\right)$ & 2870 & 2715 \\
Boiling temperature $\left({ }^{\circ} \mathrm{C}\right)$ & 6000 & - \\
Thermal expansion coefficient & 5.8 & $5-10$ \\
$\quad\left(\mu \mathrm{m} \mathrm{m}^{-1} \mathrm{~K}^{-1}\right)$ & & \\
Radiation coefficient $\left(\mathrm{n}_{\mathrm{D}}\right)$ & 3.19 & - \\
Grain size $(\mu \mathrm{m})$ & 100 & 80 \\
Crystallographic structure & Hexagonal, hP2 & - \\
Colour & Black & White \\
\hline
\end{tabular}

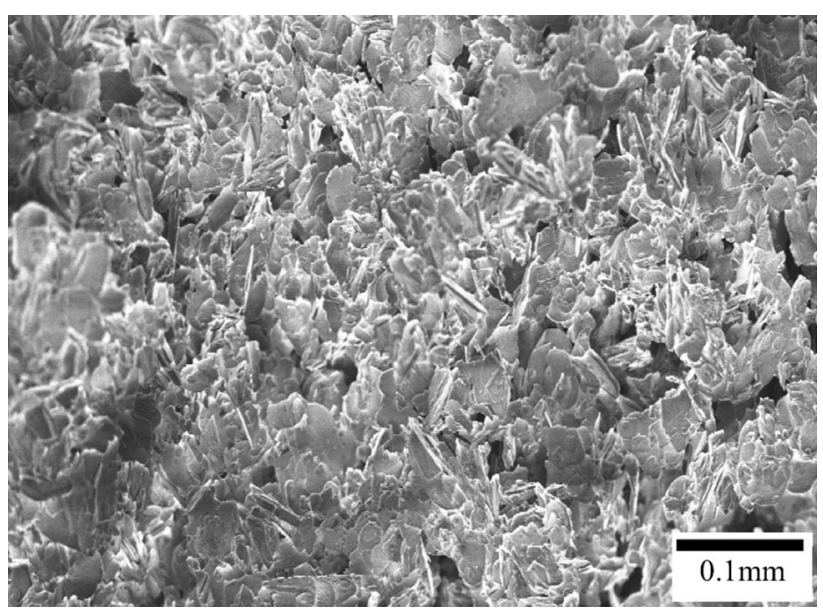

Fig. $1 \mathrm{ZrO}_{2}$ ceramic oxide powder used for alloying

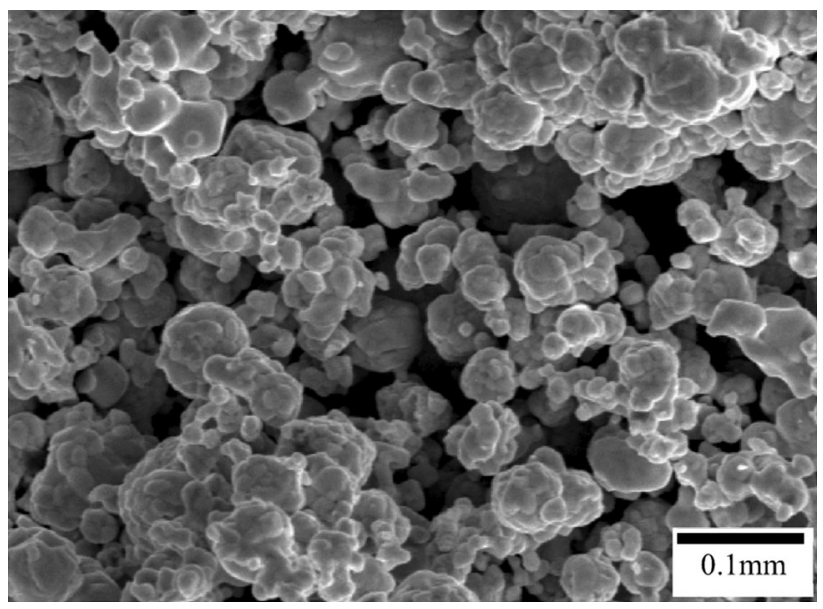

Fig. 2 WC ceramic oxide powder used for alloying

\subsection{Apparatus and methods}

In order to search for optimum laser treatment process results, it is necessary to take into consideration all process 
parameters. Factors, like laser beam power, its traverse speed, amount of protective gas dose, amount of alloying powder feed, powder morphology, including size, shape, wettability, even colour, have significant influence on run's formation. In case of this paper, parameters like laser power, its traverse speed and amount of powder feed have been considered within its influence on run morphology and wear resistance.

Surface treatment was carried out using high-power diode laser HPDL Rofin Sinar DL 020 which is presented in Fig. 3. Device consists of head equipped with two packets of diodes which are powered from separate energy sources, control unit and cooling system. Positioning of laser head is being done thanks to numerical control, whose precision is $0.20 \mu \mathrm{m}$ on every $100 \mathrm{~mm}$. Maximum power output for laser beam is $2500 \mathrm{~W}$. The device is also equipped with automated system of powder feeding into the molten pool which is able to transport $0.8-25 \mathrm{~g}$ of any powder with granulation in the range of $40-70 \mu \mathrm{m}$ in 1-min time. Technical details of HPDL ROFIN SINAR DL 020 laser are presented in Table 3. For the experiment, because of available surface limit two passes have been done on each sample. With following passes, traverse speeds and output powers were changed. Parameters of all experiments are listed in Table 3.

Laser scan rate was chosen experimentally in one of the previous works. A suitable reference range was chosen from 0.1 to $1 \mathrm{~m} / \mathrm{min}$, because for other materials the observed trends and surface behaviour are similar, but can differ significantly in relation to the selected ceramic powder-in this case $\mathrm{WC}$ and $\mathrm{ZrO}_{2}$ powders. Laser traverse speed range was chosen from 0.25 to $0.75 \mathrm{~m} / \mathrm{min}$. There is obviously a clear relationship between the laser power applied and the achieved quality of the surface; particular investigation concerning laser power influence

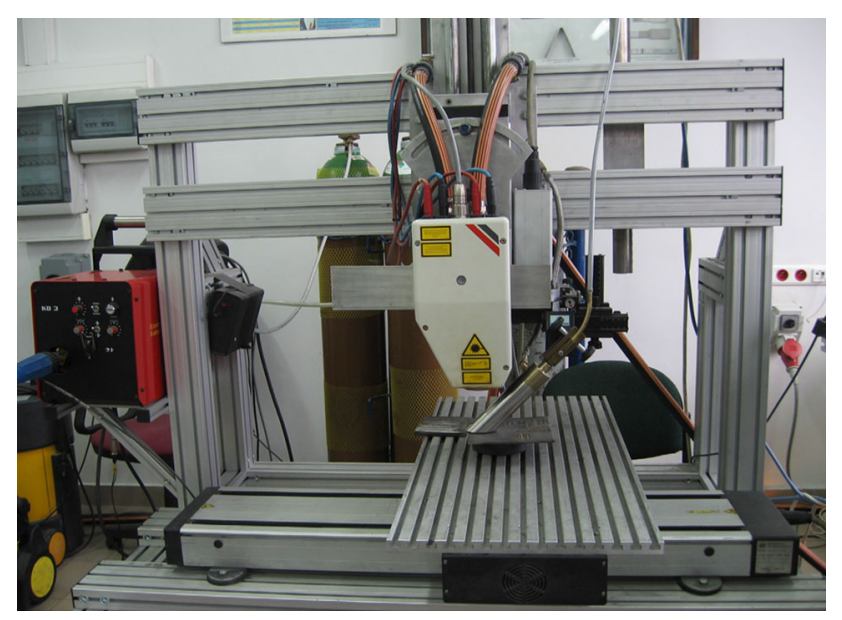

Fig. 3 High-power diode laser HPDL Rofin Sinar DL 020-used for heat treatment of aluminium alloys
Table 3 HPDL laser parameters used for alloying

\begin{tabular}{ll}
\hline Parameter & Value \\
\hline Laser wave length $(\mathrm{nm})$ & $940 \pm 5$ \\
Available power range $(\mathrm{W})$ & $100-2300$ \\
Focus length of the laser beam $(\mathrm{mm})$ & $82 / 32$ \\
Power density range of the laser beam in the & $0.8-36.5$ \\
$\quad$ focus plane $\left(\mathrm{kW} / \mathrm{cm}^{2}\right)$ & $1.8 \times 6.8$ \\
Dimensions of the laser beam focus $(\mathrm{mm})$ & \\
\hline
\end{tabular}

was carried out in former works. It was found out that the optimal laser power does not exceed $1.5 \mathrm{~kW}[1,2]$.

The feeding and remelting was performed in argon protective atmosphere, in order to protect the substrate as well as the ceramic particles from oxidation. Protective gas nozzles are pointed directly in spot of molten pool formation place. The other nozzle whose role was powder feeding was pointed to the weld area at $45^{\circ}$ angle of tilt to the substrate surface. Flow rate of shielding gas, 10 1/min, (argon) was constant for all trials, whereas the fluidisation rate was chosen experimentally to meet the optimal feeding depth of the ceramic powder.

Distance from the sample was set in the range of ca. $20 \mathrm{~mm}$, because a too large distance would extend the area of argon protection, waste of argon and ceramic powder. Finally on the surface of each rectangular sample was performed one track with different laser powers and at a laser scan rate of $0.5 \mathrm{~m} / \mathrm{s}$.

Coated samples were sectioned perpendicular to the laser track by the line cutting machine to obtain the crosssectional view. Struers Discotom-60 was used for the job because of its adjustable parameters of work, e.g. feed speed in range starting from $0.01 \mathrm{~mm} / \mathrm{s}$. In next step, sample was polished on Struers LaboPol-25 machine suitable for grinding, lapping and polishing. Machine contains of two discs with controllable rotational speed in range of 50-500 rpm.

For the investigation of laser-treated surface layers, the following techniques and methods were applied:

micrographs of the macrostructure were performed using the light microscope Leica MEF4A in a magnification up to $50 \times$ using bright field,

microstructure investigations were also carried out on the scanning electron microscope ZEISS Supra 35 with a magnification up to $8500 \times$. For microstructure evaluation, the backscattered electrons (BSE) as well as the secondary electron (SE) detection method was used, with the accelerating voltage up to $25 \mathrm{kV}$,

chemical composition investigations using energy-dispersive spectroscopy microanalysis (EDS) was carried out on the scanning electron microscope Zeiss Supra, 
the hardness was measured with Rockwell hardness tester with a load chosen for the HRF scale, with a load of $60 \mathrm{Kgf}$,

depth of the remelted area was measured based on the cross-sectional structures obtained on the scanning electron microscope,

wear resistance of the produced quasi-composite surface layer was measured using the Surtronic $3+$ profilometer supplied by Taylor-Hobson. The surfaces of the specimens were cleaned using methanol and dried in compressed air, then arithmetic mean deviation and wear depth profiles were obtained.

\section{Results and discussion}

\subsection{Microstructure and hardness investigation}

Structural investigations carried out using the high-power diode laser allow comparing the surface layer as well as shape and depth of beads. It was found that, in the case of both ceramic powders used, with increase in the laser power from 1.2 to $2.0 \mathrm{~kW}$ the porosity of the composite layers increases. For a lower laser power of ca. $1.0 \mathrm{~kW}$, there is not a linear remelting present on the whole length of the treated sample surface where for a higher laser power of ca. $2.0 \mathrm{~kW}$ the laser tray is very uneven. Researchers have also investigated influence of laser speed on run macroscopic morphology. Laser traverse speed range was chosen from 0.25 to $0.75 \mathrm{~m} / \mathrm{min}$. Use of traverse speed of $0.25 \mathrm{~m} / \mathrm{min}$ led to the formation of very rough and wide beads (Fig. 4), while use of $0.75 \mathrm{~m} / \mathrm{min}$ resulted in the formation of unalloyed runs-too high speed leads to occurrence of very weak fusion penetration (Fig. 5). Optimal value was set to $0.5 \mathrm{~m} / \mathrm{min}$ for both of the investigated aluminium alloys groups because formed beads have optimal macrostructure and roughness for further investigations (Fig. 6). Macroscopic cross sections of

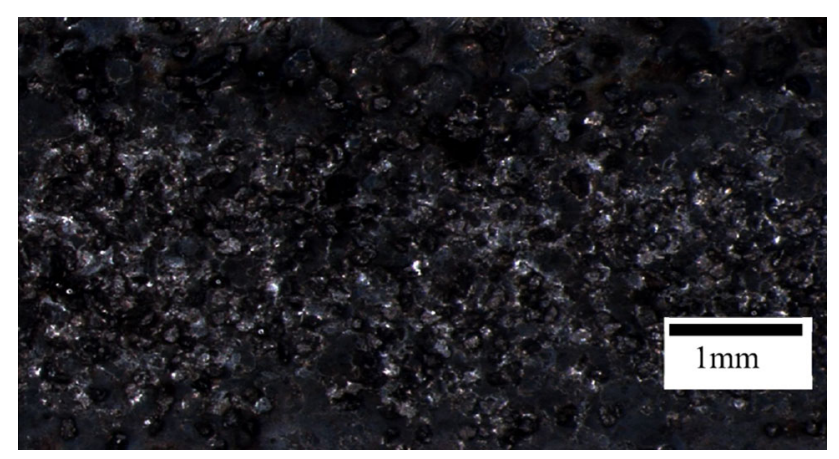

Fig. 4 Surface of the laser run face after treatment with WC powder using $1.5 \mathrm{~kW}$ laser power, scan rate $0.25 \mathrm{~m} / \mathrm{s}, \mathrm{AlSi}_{7} \mathrm{Cu}_{2}$ cast alloy

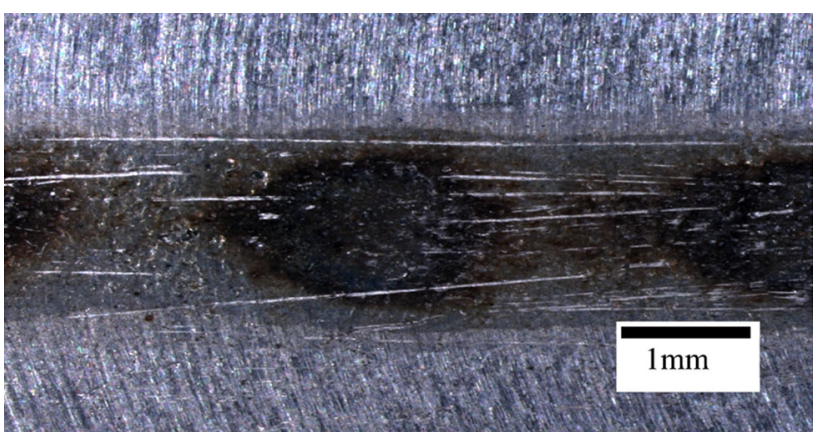

Fig. 5 Surface of the laser run face after treatment with WC powder using $1.5 \mathrm{~kW}$ laser power, scan rate $0.75 \mathrm{~m} / \mathrm{s}, \mathrm{AlSi}_{7} \mathrm{Cu}_{2}$ cast alloy

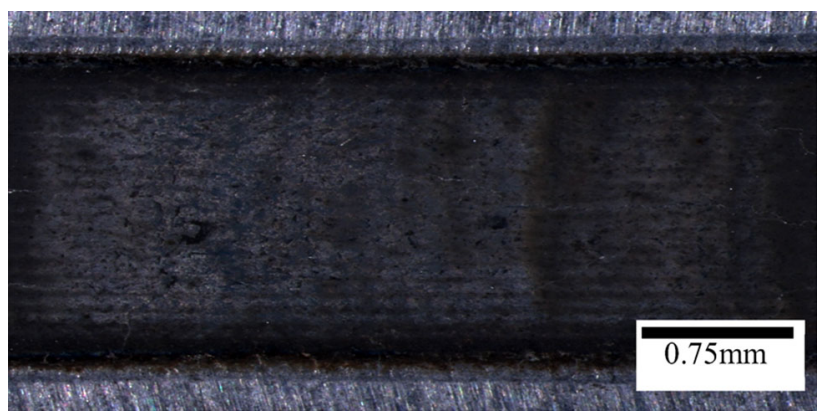

Fig. 6 Surface of the laser run face after treatment WC powder using with $1.5 \mathrm{~kW}$ laser power, scan rate $0.5 \mathrm{~m} / \mathrm{s}, \mathrm{AlSi}_{7} \mathrm{Cu}_{2}$ cast alloy

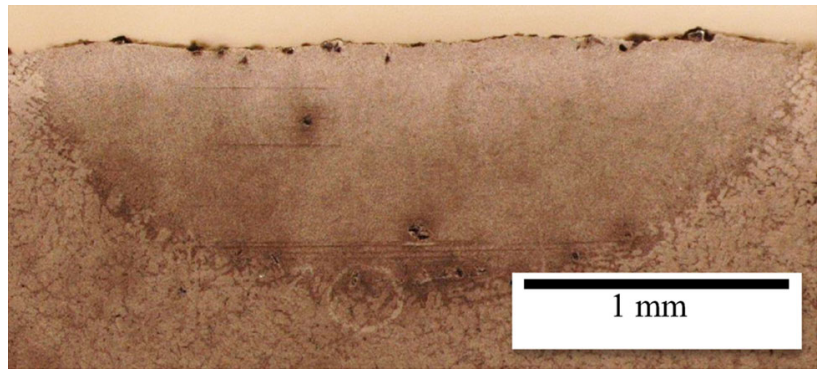

Fig. 7 Cross section of the surface layer obtained for WC powder and the $\mathrm{AlSi}_{7} \mathrm{Cu}_{2}$ alloy, $1.5 \mathrm{~kW}$ laser power, scan rate $0.5 \mathrm{~m} / \mathrm{s}$

$\mathrm{AlSi}_{7} \mathrm{Cu}_{2}$ alloyed with $\mathrm{ZrO}_{2}$ and $\mathrm{WC}$ powders using traverse speed of $0.5 \mathrm{~m} / \mathrm{min}$ and $1.5 \mathrm{~kW}$ laser beam power have been shown in Figs. 7, 8. As it can be seen in Fig. 7, run has minor roughness and thickness of approximately $1000 \mu \mathrm{m}$. Bead's cross section shown in Fig. 8 is characterized by moderate roughness and thickness of approximately $800 \mu \mathrm{m}$. In macroscopic point of view, these two runs are free of pores and cracks, with high-quality metallurgical bonding to the substrate. Beads have also symmetrical configuration of fusion area without visible macroscopic fluctuation on remelting area-substrate boundary.

Investigation results obtained with scanning electron microscope SEM ZEISS Supra reveals the cross-sectional 


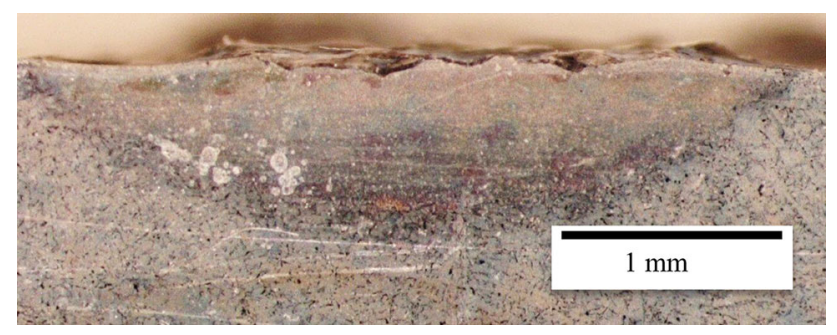

Fig. 8 Cross section of the surface layer obtained for $\mathrm{ZrO}_{2}$ powder and the $\mathrm{AlSi}_{7} \mathrm{Cu}_{2}$ alloy, $1.5 \mathrm{~kW}$ laser power, scan rate $0.5 \mathrm{~m} / \mathrm{s}$

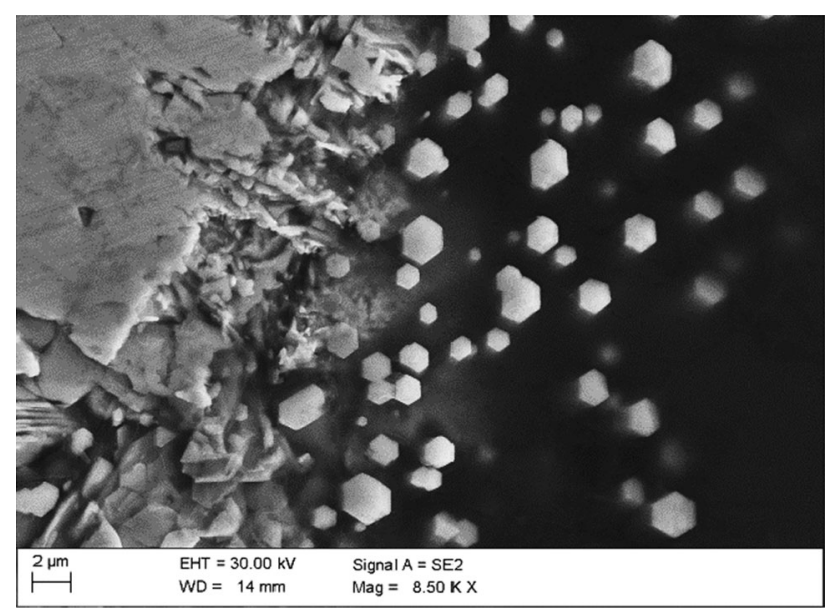

Fig. $9 \mathrm{WC}$ powder- $\mathrm{AlSi}_{7} \mathrm{Cu}_{2}$ alloy matrix after alloying $(1.5 \mathrm{~kW}$ laser power, $0.5 \mathrm{~m} / \mathrm{min}$ beam traverse speed)

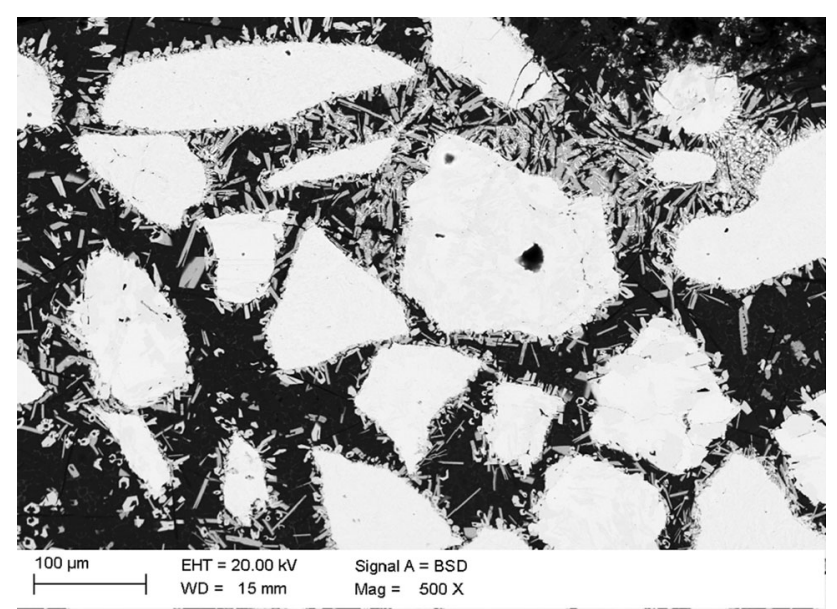

Fig. $10 \mathrm{WC}$ powder grains after alloying in the $\mathrm{AlSi}_{9} \mathrm{Cu}_{2}$ alloy matrix $(1.5 \mathrm{~kW}$ laser power, $0.5 \mathrm{~m} / \mathrm{min}$ beam traverse speed)

structure of the surface layers as well as the presently used powders (Figs. 9, 10, 12, 13, 14, 15, 16, 17, 18, 19).

Based on this investigation, distribution of powder particles in the surface layer of aluminium-silicon-copper cast alloys was presented, and it was also found that there is very small amount of pores and cracks in produced $\mathrm{ZrO}_{2}$

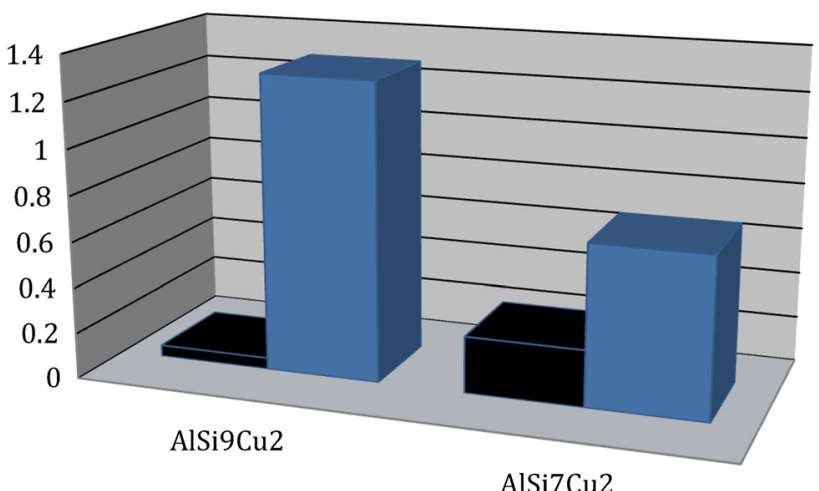

$\square \mathrm{ZrO} 2 \square \mathrm{WC}$

Fig. 11 Surface layer depth of the alloyed cast aluminium alloys with $\mathrm{ZrO}_{2}$ and WC ceramic powder

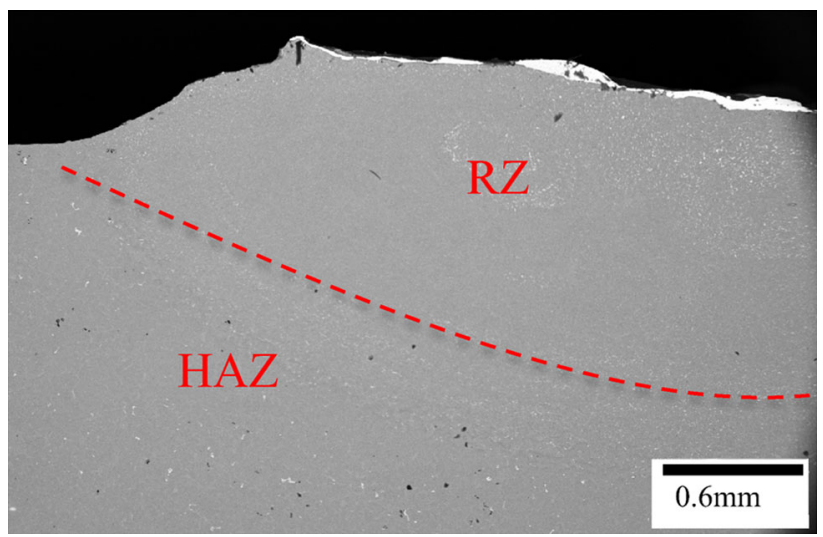

Fig. 12 Microstructure of the investigated $\mathrm{AlSi}_{7} \mathrm{Cu}_{2}$ alloy, $\mathrm{ZrO}$, $1.5 \mathrm{~kW}, 1 \mathrm{~g} / \mathrm{min}, 0.5 \mathrm{~m} / \mathrm{min}$. $R Z$ remelting zone, $H A Z$ heat-affected zone

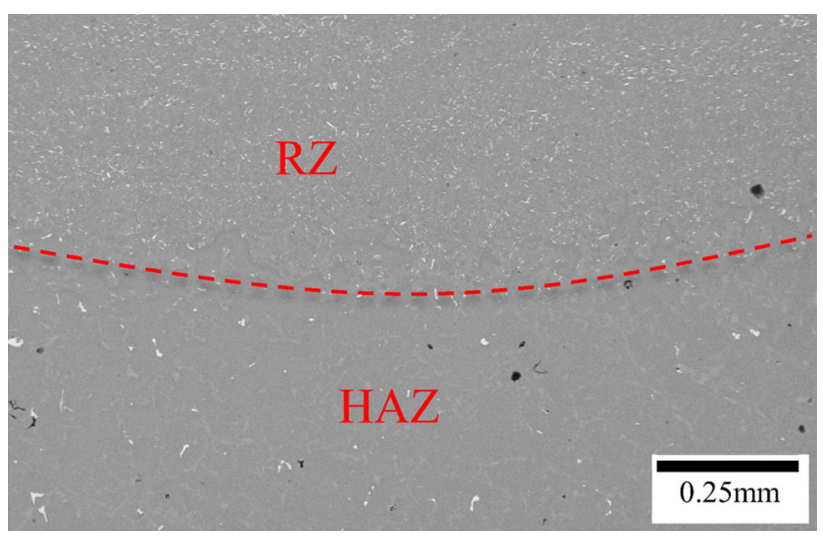

Fig. 13 Transition zone of the investigated $\mathrm{AlSi}_{7} \mathrm{Cu}_{2}$ alloy, $\mathrm{ZrO}_{2}$, $1.5 \mathrm{~kW}, 1 \mathrm{~g} / \mathrm{min}, 0.5 \mathrm{~m} / \mathrm{min}$. $R Z$ remelting zone, $H A Z$ heat-affected zone

and WC surface layers; moreover, no significant defects or failures have occurred; this finding is valid for both of the investigated alloys $\left(\mathrm{AlSi}_{7} \mathrm{Cu}_{2}\right.$ and $\left.\mathrm{AlSi}_{9} \mathrm{Cu}_{2}\right)$. Detailed 


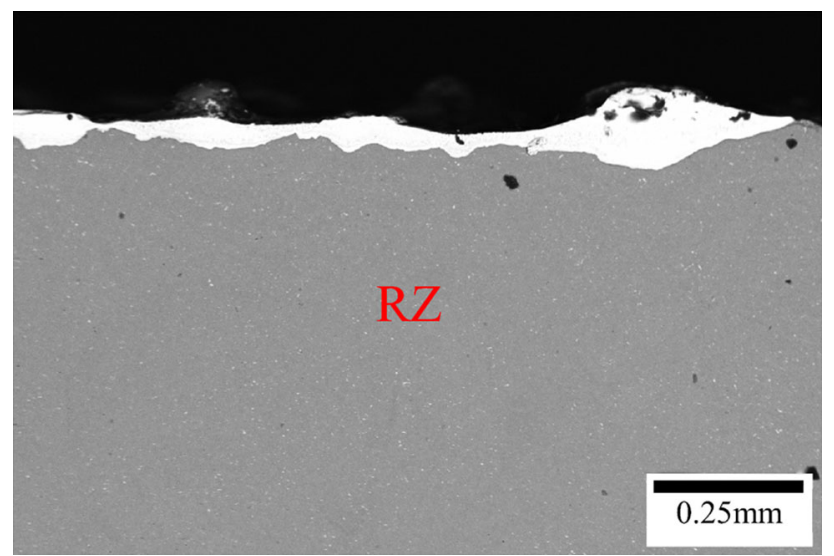

Fig. 14 Microstructure of the investigated $\mathrm{AlSi}_{9} \mathrm{Cu}_{2}$ alloy, $\mathrm{ZrO}_{2}, 1 \mathrm{~g} /$ $\min , 2 \mathrm{~kW}$. $R Z$ remelting zone

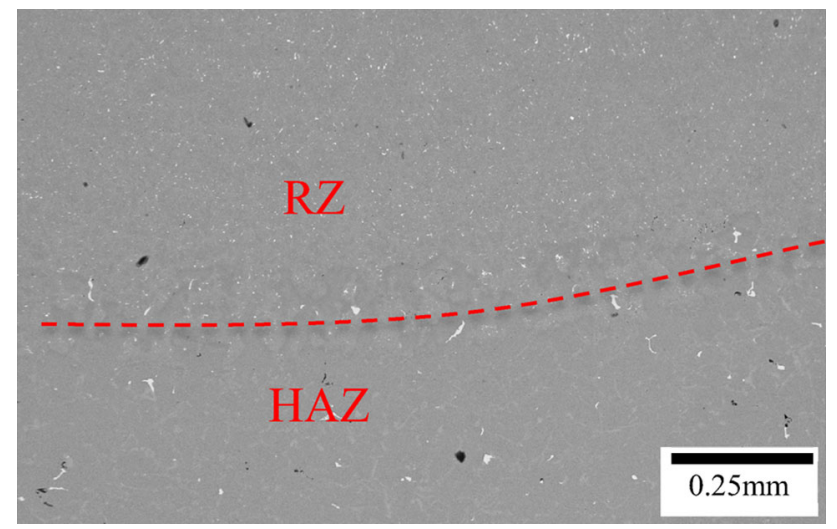

Fig. 15 Microstructure of the investigated $\mathrm{AlSi}_{9} \mathrm{Cu}_{2}$ alloy, transition zone, $\mathrm{ZrO}_{2}, 1.5 \mathrm{~kW}, 1 \mathrm{~g} / \mathrm{min}$. $R Z$ remelting zone, $H A Z$ heat-affected zone

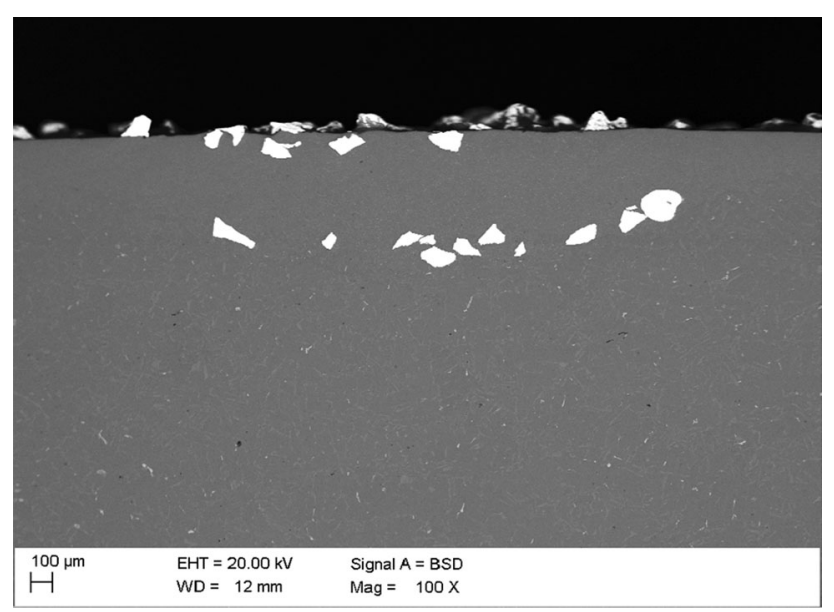

Fig. 16 Microstructure of the investigated $\mathrm{AlSi}_{7} \mathrm{Cu}_{2}$ alloy, WC, $1 \mathrm{~g} /$ $\min , 2 \mathrm{~kW}$

analysis shows occasionally discontinuity of the surface layer and ceramic particle degradation (Figs. 9, 10) for both types of matrix material. This is result of intense heat

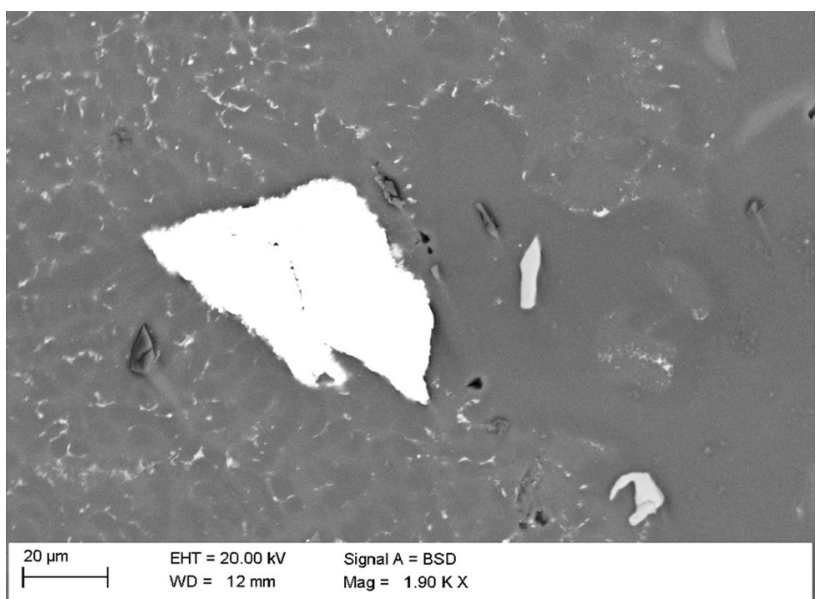

Fig. 17 Microstructure of the investigated $\mathrm{AlSi}_{7} \mathrm{Cu}_{2}$ alloy, transition zone, WC, $1.5 \mathrm{~kW}, 1 \mathrm{~g} / \mathrm{min}$

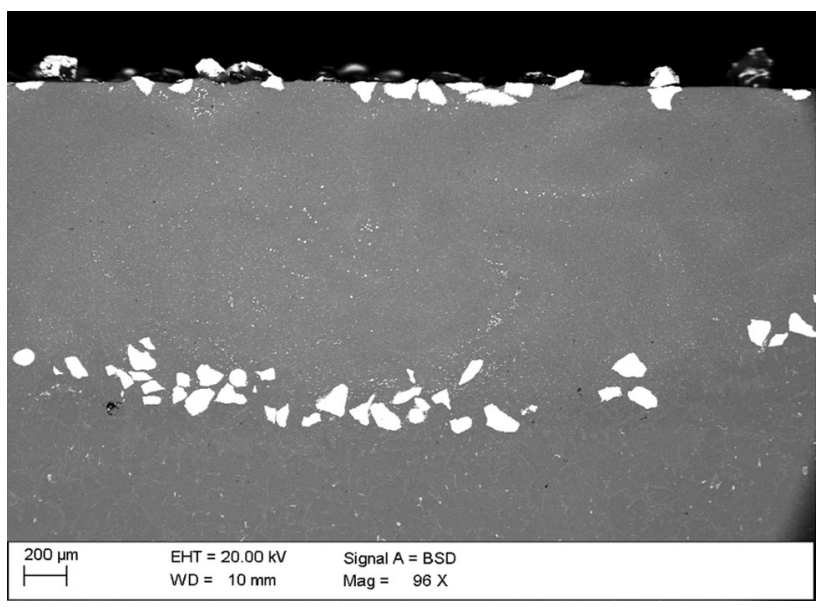

Fig. 18 Microstructure of the investigated $\mathrm{AlSi}_{9} \mathrm{Cu}_{2}$ alloy, WC, $1 \mathrm{~g} /$ $\min , 2 \mathrm{~kW}$

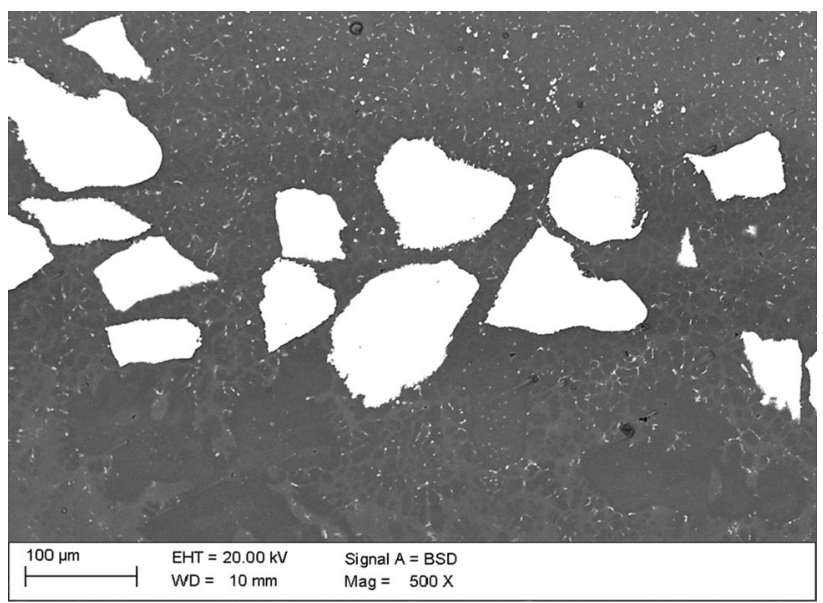

Fig. 19 Microstructure of the investigated $\mathrm{AlSi}_{9} \mathrm{Cu}_{2}$ alloy, transition zone, WC, $1.5 \mathrm{~kW}, 1 \mathrm{~g} / \mathrm{min}$ 


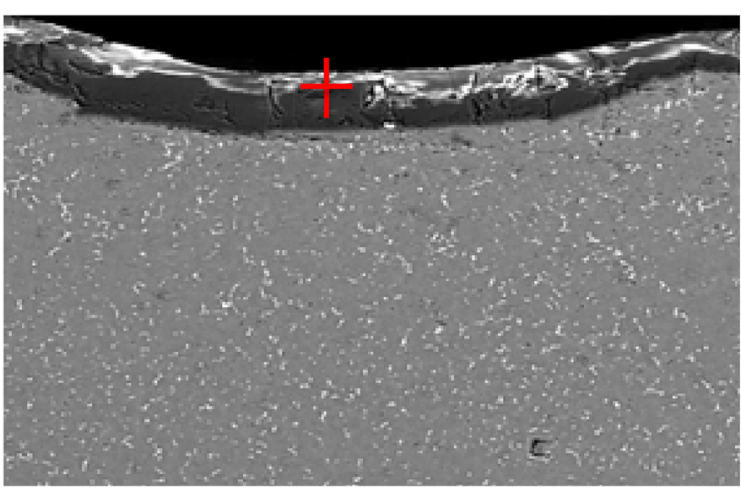

(a)

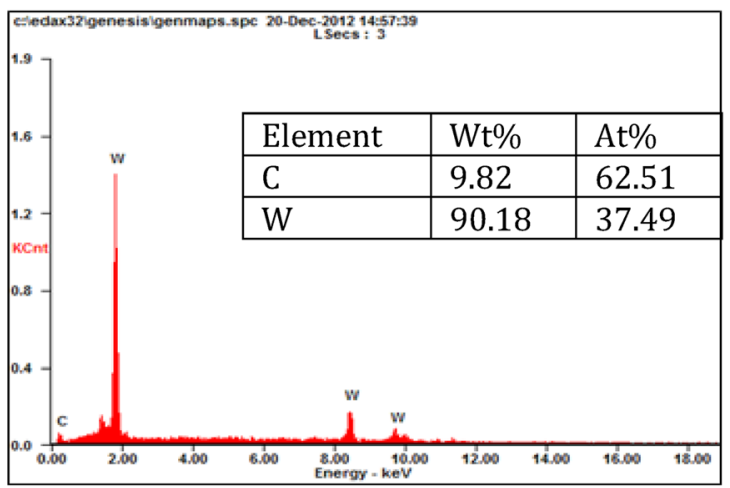

(b)

Fig. $20 \mathrm{WC}$ surface layer on the $\mathrm{AlSi}_{7} \mathrm{Cu}_{2}$ alloy (a), EDS point-wise microanalysis from the marked place (b)

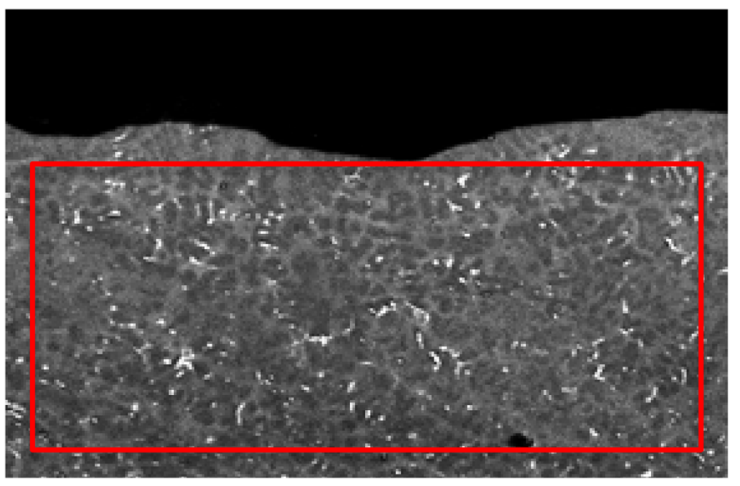

(a)

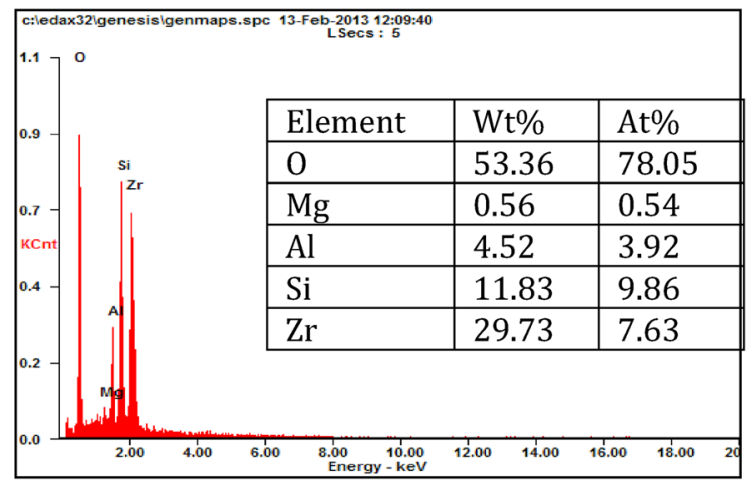

(b)

Fig. $21 \mathrm{ZrO}_{2}$ Surface layer on the $\mathrm{AlSi}_{7} \mathrm{Cu}_{2}$ alloy (a), EDS point-wise microanalysis from the marked place (b)

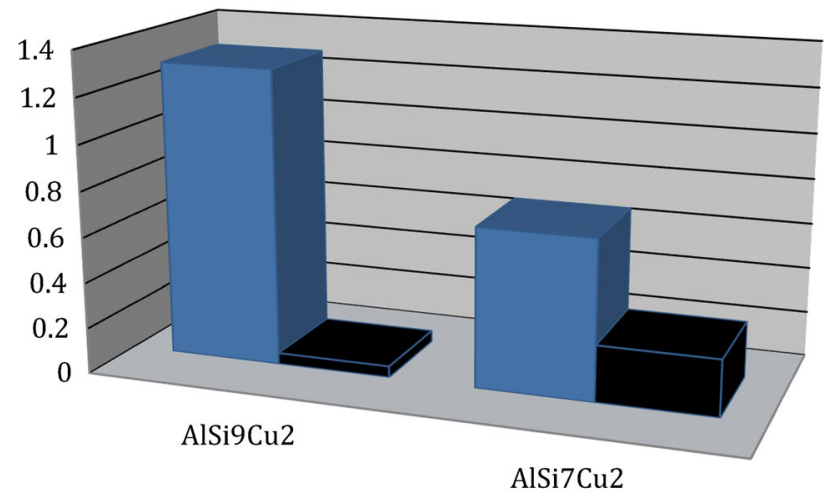

口AlSi9Cu2 $\mathbf{Z r O 2}$

Fig. 22 Surface layer hardness of the alloyed cast aluminium alloys with $\mathrm{ZrO}_{2}$ and WC ceramic powders

transfer put together with convectional and gravitational flow of molten pool. Depending on type of substrate, laser power, its traverse speed, powder sort, surface may be heated in non-uniform way, which has great impact on layer forming. Some of substrate material and additional powder undergo disintegration and evaporation influenced by high temperature which is constantly connected with laser treatment; this is why in some places characteristic pits occur. Proper adjustment of laser treatment parameters may lead to formation of high-quality uniform layers.

On the basis of cross-sectional micrographs, surface layer depths were evaluated. It reaches a range from $0.05 \mathrm{~mm}$ for $\mathrm{ZrO}_{2}$ alloying to $1.3 \mathrm{~mm}$ for $\mathrm{WC}$ alloying (Fig. 11) in the case of the $\mathrm{AlSi}_{9} \mathrm{Cu}_{2}$ alloy; for the $\mathrm{AlSi}_{7-}$ $\mathrm{Cu}_{2}$ alloy structure, investigation results allow confirming only a minor amount of the $\mathrm{ZrO}_{2}$ powder on the surface of the treated alloy. In the case of the $\mathrm{ZrO}_{2}$ powder, particles are sintered building a layer on the top of the laser-treated aluminium surface (Figs. 12, 13, 14, 15). An increase in layer's thickness is a result of low traverse speed and high power-in that conditions more powder can be fused into substrate. Thickest layers were formed using high laser traverse speed and low power, where considerably less powder is able to fuse.

There are many uneven areas and hollows in the surface layer of the $\mathrm{Al}-\mathrm{Si}-\mathrm{Cu}$ alloys after laser alloying with zirconium oxide powder. Depending on the type of substrate, 
Fig. 23 Wear resistance test profile for $\mathrm{AlSi}_{7} \mathrm{Cu}_{2}$ and $\mathrm{AlSi}_{9} \mathrm{Cu}_{2}$ cast aluminium alloy alloyed with $\mathrm{WC}$ and $\mathrm{ZrO}_{2}$ powders

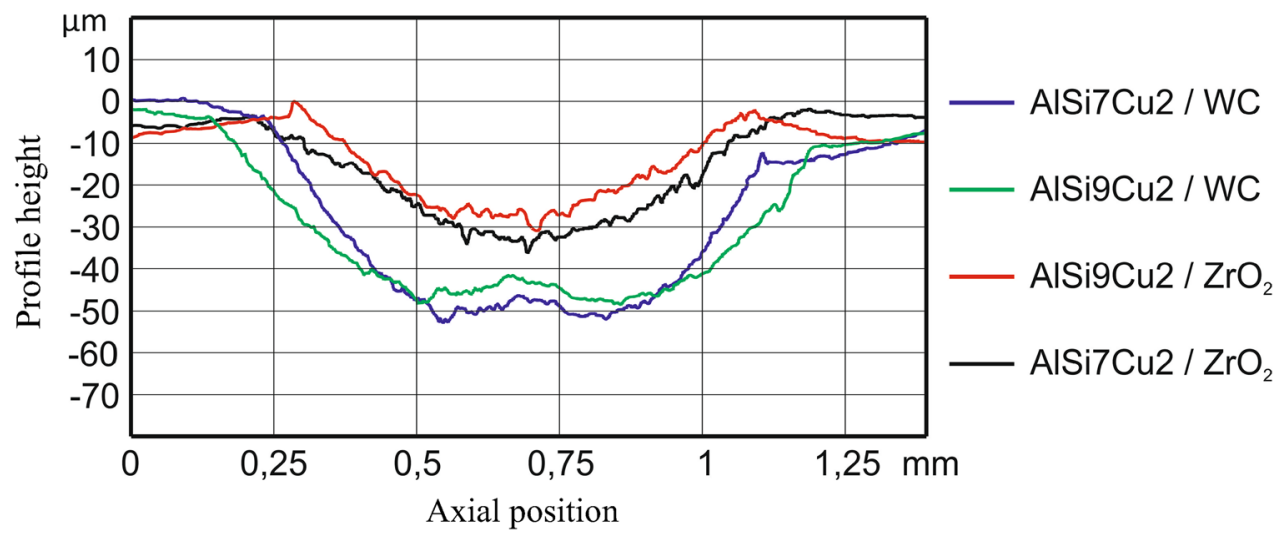

surface on which high gradient of surface tension is produced is unevenly heated, which has a direct influence on the formation of the melted material in the molten pool also in the case of WC alloying; however, $\mathrm{AlSi}_{7} \mathrm{Cu}_{2}$ alloy gives better results. The WC particles are homogenously distributed in the surface layer (Figs. 16, 17, 18, 19).

As it can be found for both investigated alloys used WC and $\mathrm{ZrO}_{2}$ powders form a sintered layer on the surface, confirmed by the EDX analysis of the chemical composition (Figs. 20, 21). Figure 21 shows thick surface layer formed on $\mathrm{AlSi}_{7} \mathrm{Cu}_{2}$ by fused WC powder, while Fig. 21 points out that $\mathrm{AlSi}_{7} \mathrm{Cu}_{2}$ alloying with $\mathrm{ZrO}_{2}$ resulted in the formation of layer characterized by uniform dissolution of alloying element in the form of dendrites.

In the case of surface layer depth, the thickness is higher in the case of WC powder alloying for both of the investigated alloys and in the $\mathrm{ZrO}_{2}$ powder alloying, the surface layer on the $\mathrm{AlSi}_{7} \mathrm{Cu}_{2}$ is higher-equal $0.25 \mathrm{~mm}$, calculated as a mean value (Fig. 11). The same relation is observed concerning the hardness of the obtained layers (Fig. 22), the highest one is achieved for the $\mathrm{WC}$ alloying of the $\mathrm{AlSi}_{9} \mathrm{Cu}_{2}$ alloy as high as $77 \mathrm{HRF}$. For $\mathrm{ZrO}_{2}$ alloying there is only a low difference between the non-treated aluminium alloy and laser-alloyed materials.

In general, metallographic observations of the microstructure carried out in small range of magnification between 100 and 200 times have revealed a difference of the surface face size and roughness in the case of these two investigated alloy groups with $\mathrm{Si} 9 \%$ and $\mathrm{Si} 7 \%$ silicon content, where for the $\mathrm{AlSi}_{9} \mathrm{Cu}_{2}$ there are more regular and uniform bead's faces compared to the $\mathrm{AlSi}_{7} \mathrm{Cu}_{2}$ alloys with a weaker and more non-uniform face. With increase in laser beam's power density or scanning speed decrease, thickness of the resulting layer increases. Lower laser beam's power density or its higher scan speed results in surface layer thickness decrease. These values should be within the proper range, because of a high power density laser beam or a low-speed scanning, alloying material begins to sublimate, leaving small pits on the surface. If the laser beam power density is too low or scanning speed is too high, structure of obtained layer may be heterogeneous.

\subsection{Wear resistance}

Proper choice of the reinforcing material determines also the wear resistance. One of the assumptions was to achieve an optimal-in the case of further appliance-wear resistance. Investigation results, measured by the ball-on-plate method, reveal that in the case of WC alloying an increase in the wear resistance occurs compared to $\mathrm{ZrO}_{2}$ alloyed material (Fig. 23). The obtained difference is relatively huge, achieving up to $50 \%$ concerning the depth of the wear resistance profile, which was take into account for the determination of this mechanical property. The wear resistance is depending also on the used aluminium alloy substrate; for the $\mathrm{AlSi}_{9} \mathrm{Cu}_{2}$, the wear resistance is higher with a wear depth of only $20 \mu \mathrm{m}$ (Fig. 23). This higher wear resistance of the $\mathrm{AlSi}_{9} \mathrm{Cu}_{2}$ alloy is caused by higher amount of silicon, building Si-precipitates, relatively hard phase leading to the enhancement of the entire alloy structure. The difference in wear resistance of the abstained surface layer was caused by uniform alumina formation on the top of the treated material which resulted in enhancement of the antiwear properties because of $\mathrm{Al}_{2} \mathrm{O}_{3}$ 's high abrasive wear resistance and its great tightness to base material. In the case of the WC-treated substrate, the tungsten carbide particles, however present in the Al-matrix, influence only partially the material surface, so its input in relation to increasing the wear resistance is determined by the amount of the WC particles embedded in the surface layer and could be increased the fed particles during laser treatment.

\section{Conclusions}

Investigations of the microstructure evaluation of the $\mathrm{AlSi}_{7} \mathrm{Cu}_{2}$ and $\mathrm{AlSi}_{9} \mathrm{Cu}_{2}$ cast aluminium alloys treated with HPDL laser for alloying are carried out using light and 
scanning electron microscope confirmed zone-like nature surface layers.

Three subzones in the obtained surface layer were revealed: the remelted zone (RZ), heat-affected zone (HAZ) on the top of the substrate material and a transition zone. Unfortunately, $\mathrm{ZrO}_{2}$ particles did not mix with substrate material that would result in the formation of $\mathrm{ZrO}_{2}$ solid layer on the top.

It was found that:

1. The optimal laser power is in the range of $<1.0-2.0>\mathrm{kW}$ and the laser scan rate as much as $0.5 \mathrm{~m} / \mathrm{s}$.

2. WC particles are very well fed into the aluminium matrix; however, further investigations are necessary to determine process parameters so that the WC powder fulfil the entire surface layer area.

3. $\mathrm{ZrO}_{2}$ powder particles did not fed into the aluminium alloy matrix during laser alloying, instead there have been formed a sintered layer onto the investigated aluminium cast alloy.

4. $\mathrm{AlSi}_{7} \mathrm{Cu}_{2}$ alloy after alloying has a more homogeneous layer surface compared to $\mathrm{AlSi}_{9} \mathrm{Cu}_{2}$ alloy and is a substrate that ensures more uniform WC powder distribution in the surface area.

5. Occasionally occurred discontinuity of the surface layer and ceramic particle degradation for both types of the matrix material can be seen as result of intense heat transfer put together with convectional and gravitational flow of molten pool. Depending on the type of substrate, laser power, its traverse speed, powder sort, surface may be heated in non-uniform way, which has great impact on layer forming. Some of substrate material and additional powder undergo disintegration and evaporation influenced by high temperature which is constantly connected with laser treatment; this is why, in some places characteristic pits occur. Proper adjustment of laser treatment parameters may lead to formation of high-quality uniform layers.

6. With increase in laser beam's power density or scanning speed decrease, thickness of the resulting layer increases. Lower laser beam's power density or its higher scan speed results in decreased surface layer thickness.

The planned investigation will allow a more accurate analysis of the nature of the interactions between different layers and will allow a more precise description of the morphology of the obtained layers.

Acknowledgments This publication was financed by the Ministry of Science and Higher Education of Poland as the statutory financial Grant of the Faculty of Mechanical Engineering SUT.
Open Access This article is distributed under the terms of the Creative Commons Attribution 4.0 International License (http://crea tivecommons.org/licenses/by/4.0/), which permits unrestricted use, distribution, and reproduction in any medium, provided you give appropriate credit to the original author(s) and the source, provide a link to the Creative Commons license, and indicate if changes were made.

\section{References}

1. K. Labisz, Forming the structure and surface properties of cast Al-Si-Cu alloys. Open Access Libr. 5(23), 1-152 (2013). (in Polish)

2. K. Labisz, Microstructure and mechanical properties of high power diode laser (HPDL) treated cast aluminium alloys. Materialwiss. Werkstofftech. 45(4), 314-324 (2014). doi:10.1002/ mawe. 201400231

3. A. Lisiecki, Welding of thermomechanically rolled finegrain steel by different types of lasers. Arch. Metall. Mater. 59(4), 1625-1631 (2014). doi:10.2478/amm-2014-0276

4. T. Tański, Determining of laser surface treatment parameters used for light metal alloying with ceramic powders. Materialwiss. Werkstofftech. 45, 333-343 (2014). doi:10.1002/mawe. 201400232

5. L.A. Dobrzański, K. Labisz, M. Piec, A.J. Lelątko, A. Klimpel, Structure and properties of the $32 \mathrm{CrMoV} 12-28$ steel alloyed with WC powder using HPDL laser. Mater. Sci. Forum 530-531, 334-339 (2006). doi:10.4028/www.scientific.net/MSF.530-531.334

6. W. Pakieła, T. Tański, Z. Brytan, K. Labisz, The influence of laser alloying on the structure and mechanical properties of AlMg5Si2Mn surface layers. Appl. Phys. A 122(4), 352-360 (2016). doi:10.1007/s00339-016-9834-z

7. Y. Suna, S. Hanakia, M. Yamashitaa, H. Uchidaa, H. Tsujiib, Fatigue behaviour and fractography of laser-processed hot work tool steel. Vacuum 73(3-4), 655-660 (2004). doi:10.1016/j. vacuum.2003.12.161

8. L.J. Yang, Wear coefficient of tungsten carbide against hot-work tool steel disc with two different pin settings. Wear 257(5-6), 481-495 (2004). doi:10.1016/j.wear.2004.01.014

9. K. Dae-Hwan, H. Seong-Hyeon, K. Byoung-Kee, Fabrication of ultrafine $\mathrm{TaC}$ powders by mechanochemical process. Mater. Lett. 58(30), 3863-3867 (2004). doi:10.1016/j.matlet.2004.07.038

10. X. Changqing, J. Yucheng, Y. Guangli, Effect of a single peak overload on physically short fatigue crack retardation in an axlesteel. Fatigue Fract. Eng. Mater. Struct. 19(2-3), 201-206 (1996). doi:10.1111/j.1460-2695.1996.tb00959.x

11. R. Filip, Laser nitriding of the surface layer of Ti6Al4 V titanium alloy. Arch. Mater. Sci. Eng. 30(1), 25-28 (2008)

12. E. Kennedy, G. Byrne, D.N. Collins, A review of the use of high power diode lasers in surface hardening. J. Mater. Process. Technol. 155-156, 1855-1860 (2004). doi:10.1016/j.jmatprotec. 2004.04.276

13. M. Bonek, L.A. Dobrzański, Characterization performance of laser melted commercial tool steels. Mater. Sci. Forum 654-656, 1848-1851 (2010). doi:10.4028/www.scientific.net/MSF.654656.1848

14. M. Bonek, G. Matula, L.A. Dobrzanski, Effect of laser surface melting on structure and properties of a high speed tool steel. Adv. Mater. Res. 291-294, 1365-1368 (2011). doi:10.4028/ www.scientific.net/AMR.291-294.1365

15. Z. Brytan, J. Niagaj, Microstructural characterization of lean duplex stainless steel UNS S32101 welded joints using electron backscatter diffraction. Chiang Mai J. Sci. 40(5), 923-937 (2013) 
16. G. Lili, Z. Chunhong, Z. Milin, H. Xiaomei, S. Nan, The corrosion of a novel Mg-11Li-3Al-0.5RE alloy in alkaline $\mathrm{NaCl}$ solution, International. J. Alloys Compd. 468(1-2), 285-289 (2009). doi:10.1016/j.jallcom.2007.12.080

17. R. Bidulsky, M.A. Grande, Z. Brytan, M. Rosso, Effect of different vacuum heat treatments on the microstructure of a low alloyed sintered steel. Mater. Sci. Forum 672, 293-296 (2011). doi:10.4028/www.scientific.net/MSF.672.293

18. Y. Issshiki, K. Mizumoto, M. Hashimoto, Synthesis of irontungsten alloy on mild steel by laser surface alloying. Thin Solid Films 317(1-2), 468-470 (1998). doi:10.1016/S00406090(97)00563-4

19. L.A. Dobrzański, T. Tański, J. Trzaska, Optimization of heat treatment conditions of magnesium cast alloys. Mater. Sci. Forum 638-642, 1488-1493 (2010). doi:10.4028/www.scientific.net/ MSF.638-642.1488

20. A.D. Dobrzańska-Danikiewicz, T. Tański, J. Domagała-Dubiel, Unique properties, development perspectives and expected applications of laser treated casting magnesium alloys. Arch.
Civil Mech. Eng. 12, 318-326 (2012). doi:10.1016/j.acme.2012. 06.007

21. T. Tański, W. Pakieła, D. Janicki, B. Tomiczek, M. Król, Properties of the aluminum alloy EN AC 51100 after the laser surface treatment. Arch. Metall. Mater. 61(1), 199-204 (2016). doi:10. 1515/amm-2016-0034

22. M. Gwoździk, Z. Nitkiewicz, Analysis of crystallite size and lattice deformations changes in an oxide layer on P91 steel. Arch. Metall. Mater. 58(1), 31-34 (2013). doi:10.2478/v10172-0120146-9

23. M. Gwoździk, Z. Nitkiewicz, Studies on the adhesion of oxide layer formed on X10CrMoVNb9-1 steel. Arch Civ Mech Eng 14, 335-341 (2014). doi:10.1016/j.acme.2013.10.005

24. L.A. Dobrzański, M. Krupinski, K. Labisz, B. Krupinska, A. Grajcar, Phases and structure characteristics of the near eutectic $\mathrm{Al}-\mathrm{Sl}-\mathrm{Cu}$ alloy using derivative thermo analysis. Mater. Sci. Forum 638-642, 475-480 (2010). doi:10.4028/www.scientific. net/MSF.638-642.475 